\title{
PRELIMINARY RESULTS ON NARROW-LEAVED ASH (FRAXINUS ANGUSTIFOLIA VAHL) AND GREEN ASH (FRAXINUS PENNSYLVANICA MARSHALL) SEED ENTOMOFAUNA IN CROATIA
}

\author{
PRELIMINARNI REZULTATI ISTRAŽIVANJA ENTOMOFAUNE \\ SJEMENA POLJSKOG (Fraxinus angustifolia Vahl) \\ I PENSILVANSKOG JASENA (Fraxinus pennsylvanica \\ Marshall) U HRVATSKOJ
}

Jelena KRANJEC ORLOVIĆ ${ }^{1}$, Ida BULOVEC ${ }^{2 *}$, Milivoj FRANJEVIĆ ${ }^{1}$, Damjan FRANJEVIĆ ${ }^{3}$, Josip SKEJO ${ }^{3}$ Marin BILIŠKOV ${ }^{3}$, Danko DIMINIĆ' ${ }^{1}$ Boris HRAŠOVEC ${ }^{1}$

\begin{abstract}
SUMIMARY
Native narrow-leaved ash (Fraxinus angustifolia Vahl) and introduced green ash (F. pennsylvanica Marshall) are two most common ash (Fraxinus spp.) species in Croatian lowland forests, taking a significant place in these ecosystems. In the recent past it has been observed that narrow-leaved ash seed yields have reduced, emphasising the importance of good health status of those collected, as they are used for seedling production and consecutive regeneration of forest stands or afforestation. Given that insects could be an important factor affecting ash seed health status, the aim of this research was to gain insight into the species being present and their frequency in the ash seeds. In total 2.500 narrow-leaved ash and 1.000 green ash seeds from seven different locations were screened for insect presence. Analysed seeds were categorized as undamaged, insect damaged or empty, and observed insect specimens were identified by morphological and molecular genetic analysis. Green ash seeds revealed higher insect infestation in comparison with native ash species, with weevil Lygniodes bischoffii being the most numerous pest found. Narrow-leaved ash seeds were mostly occupied by the native weevil species, L. enucleator. Besides these pests, larval, pupal, and adult stages of parasitoid wasps (Hymenoptera) and larval stage of the seed eating moth Pseudargyrotoza conwagana (Lepidoptera) were found in both ash species. However, given that pests detected in this study prefer urban areas or were present in a very small number of seeds, where they were often followed by parasitoids, it can be concluded that insects currently do not have a significant negative impact on the reproduction of narrow-leaved ash and green ash in forest stands.
\end{abstract}

KEY WORDS: ash, seed damage, weevils, Lygniodes, parasitoid wasps, Pseudargyrotoza conwagana

dr. sc. Jelena Kranjec Orlović, jkranjec@sumfak.unizg.hr; doc. dr. sc. Milivoj Franjević, mfranjevic@sumfak.unizg.hr; prof. dr. sc. Danko Diminić, ddiminic@sumfak.unizg. hr; prof. dr. sc. Boris Hrašovec, hrasovec@sumfak.unizg.hr, University of Zagreb, Faculty of Forestry and Wood Technology, Department of Forest Protection and Wildlife Management, Svetošimunska cesta 23, 10000 Zagreb, Republic of Croatia

${ }^{2}$ Ida Bulovec, mag. ing. silv., i.bulovec@yahoo.com, Bukovačka cesta 302a, 10000 Zagreb, Republic of Croatia (corresponding author)

3 izv. prof. dr. sc. Damjan Franjević, damjan.franjevic@biol.pmf.unizg.hr; dr. sc. Josip Skejo, josip.skejo@biol.pmf.unizg.hr; Marin Biliškov, mbiliskov@stud.biol.pmf. unizg.hr, University of Zagreb Faculty of Science, Department of Biology, Rosseveltov trg 6, 10000 Zagreb, Republic of Croatia

${ }^{*}$ Autor za korespodenciju (corresponding author) 


\section{INTRODUCTION} UVOD

Narrow-leaved ash (Fraxinus angustifolia Vahl), distributed in central-southern Europe and northwest Africa, is an ecologically and economically important species in riparian and floodplain forests because of its fast growth and specific adjustments to the habitat, especially in central Europe, the Pannonian Basin and the Balkans (Temunović et al. 2012, Caudullo and Durrant 2016). It is currently suffering severe dieback in its distribution area (Gross et al. 2014), being one of the most endangered forest tree species in Croatia, mostly due to a pathogenic fungus Hymenoscyphus fraxineus (T. Kowalski) Baral, Queloz \& Hosoya (Diminić 2015, Milotić et al. 2016). Yield and health status of narrow-leaved ash seeds are thus of great significance for seedling production and consecutive afforestation or regeneration of damaged forest stands. Previous studies showed that freshly collected seeds have a very high viability even after two years of storage (87\%) and are of relatively good health status regarding fungal presence after two months of storage (Drvodelić and Oršanić 2016, Kranjec Orlović et al. 2019). However, in the last six years there is a concerning decrease in seed production of the narrow-leaved ash in Croatia in comparison to amounts collected 10-15 years ago, with yearly yields varying between 148 and $4.844 \mathrm{~kg}$ (Vincenc 2015, 2016, 2017, 2018, 2019), which emphasises the importance of good health status of these smaller amounts of collected seeds.

Another ash (Fraxinus spp.) species, Fraxinus pennsylvanica Marshall or green ash, is very common in Croatian lowland forests. Originally a North American species, it was introduced to Europe in the 19th century mostly for ornamental purposes and timber production (Schmiedel et al. 2013), and since then it has successfully spread outside designated planting areas, earning the status of an invasive species in some countries (Prots et al. 2011, Drescher and Prots 2016). In Croatia it was first planted over more than 130 years ago with the objective of improving and preparing very wet and difficult habitats for the native narrow-leaved ash. Although usually replaced with the native species after successfully fulfilling the ameliorative role, it has spontaneously spread in numerous locations and today there are individual trees, groups or even whole stands still widely present in Croatian lowland forests, taking a significant place in these ecosystems (Kremer and Čavlović 2005). Additionally, it has been observed that in both natural stands and urban areas, green ash yields more seed in comparison to the native narrow-leaved ash (unpublished data).

One of the most important biotic factors causing seed deterioration are insects, especially during the pre-dispersal phase of seed development (Janzen 1971, Turgeon et al. 1994, Hulme and Benkman 2002), as their attacks can lead to fruit abortion (Sallabanks and Courtney 1992), facilitated introduction of microbes and pathogens (Battisti et al. 1999, Luchi et al. 2011) or to reduction of the amount of seeds available for afforestation and natural regeneration of tree species (Turgeon et al. 1994, Boivin and Auger-Rozenberg 2016). Most common and known insects found in ash seeds are weevils belonging to genus Lignyodes (Coleoptera: Curculionidae) (Clark 1980). There are three known species that can be found in Europe: L. enucleator (Panzer, 1798) and $L$. suturatus (Fairmaire, 1860), which are native, and $L$. bischoff (Blatchley, 1916), an invasive species which came from the North America with green ash seeds (Dieckmann 1970, Caldara 2013). Amongst the entomofauna in seeds, hymenopteran parasitoids can also be found, as a natural way of reducing the number of seed-eating insects. Most commonly, larvae of beetles are parasitized by several wasp species that oviposit their eggs in the seeds from the seedpod surface (Nakai et al. 2011).

Generally, most studies focusing on entomofauna in the ash seeds in Europe and their impact on seed health status were conducted on common ash (Fraxinus excelsior L.) (e.g. Gardner 1977, Tapper 1992, Hayatgheibi 2013, Gosik et al. 2017), and there is little or no information about insect presence in seeds of other ash species. Therefore, this research had two main objectives: (1) to explore entomofauna of narrow-leaved ash and green ash seeds in order to gain insight into the insect species present in the most common native and introduced ash species in Croatia for future comparisons; (2) to show the frequency in which insects appear in seeds, as this could be an important factor affecting ash seed health status.

\section{MATERIALS AND METHODS MATERIJALI I METODE}

Narrow-leaved ash seeds were collected in the period from August to November 2017 from visually healthy trees in natural or specially managed forest stands registered as seed sources or seed stands (five different locations). Additional seed sampling was conducted from August to September 2018 in natural forest stands registered as the seed source HR-FAN-SI-121/305. Green ash seeds were collected in November 2018 from two different locations, one in an urban area and another in a natural forest stand (Figure 1).

One hundred seeds from each location were separated from samaras and examined for presence of insects under the stereo microscope (SMZ 168-TLED, Motic, Hong Kong, China). The seeds were categorized as undamaged (without any sign of insect presence), damaged (with presence of different life stages of insects or their exit holes), or empty (partially developed but with no endosperm). Collected insect specimens were analysed and photographed under the stereo microscope and grouped according to their morpho- 


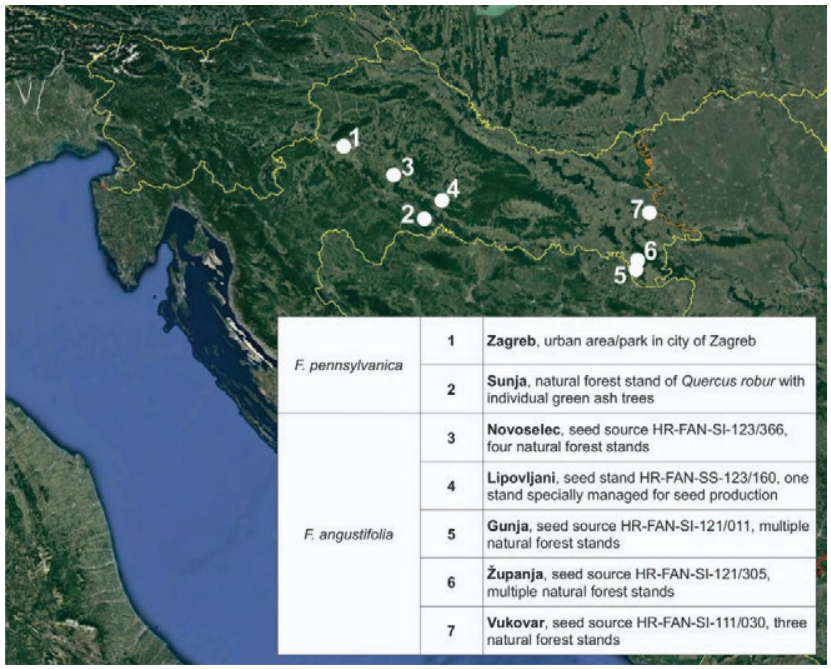

Figure 1. Map of Fraxinus angustifolia and Fraxinus pennsylvanica seed collection locations

Slika 1. Karta lokacija uzorkovanja sjemena poljskog i pensilvanskog jasena

logical characteristics into presumed insect taxa, which were preserved in $75 \%(\mathrm{v} / \mathrm{v})$ ethanol solution, each in a separate microcentrifuge tube. As the number of individuals in sampled seeds was generally low, additional 2.000 of narrow-leaved ash seeds from Županja and 800 green ash seeds from Zagreb and Sunja were examined in order to collect as much biological material as possible for species identification by molecular genetic analysis.

Total genomic DNA was extracted from ethanol-preserved specimens with DNeasy Blood \& Tissue kit (Qiagen, Hilden, Germany) according to the manufacturer's instructions. The Folmer region of mitochondrial CO1 gene (cytochrome c oxidase 1) was amplified from obtained DNA us- ing primers LCO1490 and HCO2198 (Folmer et al. 1994), in $50 \mu \mathrm{L}$ PCR reactions containing $25 \mu \mathrm{L}$ TopTaq Master Mix kit (Qiagen, Hilden, Germany), $1 \mu \mathrm{L}$ of DNA, $1 \mu \mathrm{L}$ of $10 \mu \mathrm{mol} / \mathrm{L}$ of each primer, and $22 \mu \mathrm{L}$ of distilled RNA-free water. Cycling conditions were as follows: an initial denaturation at $95^{\circ} \mathrm{C}$ for $5 \mathrm{~min}, 35$ cycles of denaturation at 94 ${ }^{\circ} \mathrm{C}$ for $1 \mathrm{~min}$, annealing at $54^{\circ} \mathrm{C}$ for $1 \mathrm{~min}$, extension at 72 ${ }^{\circ} \mathrm{C}$ for $1 \mathrm{~min}$ and a final extension step at $72^{\circ} \mathrm{C}$ for $10 \mathrm{~min}$. The resulting PCR products were purified with MinElute PCR Purification kit (Qiagen, Hilden, Germany) according to the manufacturer's protocol and sequenced at the DNA sequencing facility (Macrogen Europe, Amsterdam, The Netherlands) using PCR amplification primers. The obtained sequences were identified by comparison with reference sequences in NCBI GenBank (Benson et al. 2017) and BoLD (Ratnasingham and Hebert 2007) databases. Species were identified using both morphological and molecular data.

\section{RESULTS}

\section{REZULTATI}

Inspection of 100 seeds per location revealed that $10 \%$ or less of narrow-leaved ash seeds were damaged by insects from all locations except Vukovar, whereas more than third of green ash seeds from both locations were occupied by insects (Figure 2). In total, $10.6 \%$ of narrow-leaved ash seeds and $42 \%$ of green ash seeds displayed insect damage or presence.

Damaged seeds of both ash species contained weevil larvae (Coleoptera: Curculionidae), wasp larvae and adults (Hymenoptera), and moth larvae(Lepidoptera), while wasp pupae and fly larvae (Diptera) where found only in green

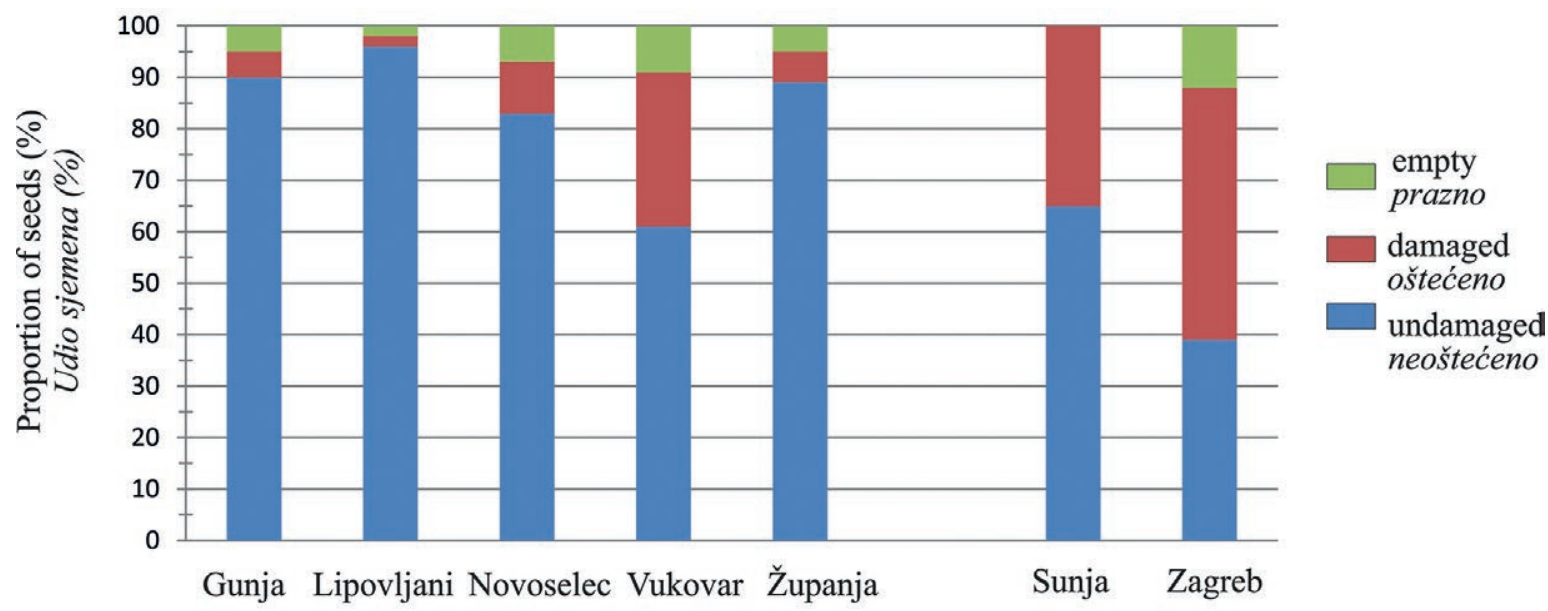

F. angustifolia

F. pennsylvanica

Figure 2. Proportion of undamaged, insect damaged and empty Fraxinus angustifolia and Fraxinus pennsy/vanica seeds from seven different locations

Slika 2. Udio neoštećenog, oštećenog i praznog sjemena poljskog i pensilvanskog jasena sakupljenog na sedam različitih lokacija 
Table 1. Numbers and locations of insect taxa and stages found in Fraxinus angustifolia and Fraxinus pennsylvanica seeds Tablica 1. Brojnost i lokacije na kojima su utvrđeni pojedini stadiji i taksoni insekata nađenih u sjemenu poljskog i pensilvanskog jasena

\begin{tabular}{|c|c|c|c|c|c|}
\hline $\begin{array}{l}\text { Ash species } \\
\text { Vrsta jasena }\end{array}$ & $\begin{array}{c}\text { Identified taxon } \\
\text { Identificirani takson }\end{array}$ & $\begin{array}{l}\text { Identification method } \\
\text { (GenBank Access. No.) } \\
\text { Metoda identifikacije } \\
\text { (GenBank identifikacijski } \\
\text { broj sekvence) }\end{array}$ & $\begin{array}{l}\text { Insect stage found in } \\
\text { the seeds } \\
\text { Stadij insekta naden u } \\
\text { sjemenu }\end{array}$ & $\begin{array}{l}\text { Number of found insect } \\
\text { specimens/total number of } \\
\text { inspected seeds } \\
\text { Broj nađenih jedinki } \\
\text { insekta / ukupan broj } \\
\text { analiziranog sjemena }\end{array}$ & $\begin{array}{l}\text { Location(s) of taxon } \\
\text { finding } \\
\text { Lokacije na kojima je } \\
\text { identificirani takson } \\
\text { prisutan }\end{array}$ \\
\hline \multirow{5}{*}{ F. angustifolia } & Lignyodes enucleator & $\begin{array}{c}\text { Molecular genetic } \\
\text { method } \\
\text { molekularno genetička } \\
\text { metoda } \\
\text { MN531297 } \\
\text { MN531298 } \\
\text { MN531299 } \\
\text { MN531300 }\end{array}$ & $\begin{array}{l}\text { larva } \\
\text { ličinka }\end{array}$ & $116 / 2.500$ & $\begin{array}{c}\text { Gunja, Lipovljani, } \\
\text { Novoselec, Vukovar, } \\
\text { Županja }\end{array}$ \\
\hline & $\begin{array}{l}\text { Pseudargyrotoza } \\
\text { conwagana }\end{array}$ & $\begin{array}{c}\text { Molecular genetic } \\
\text { method } \\
\text { molekularno genetička } \\
\text { metoda } \\
\text { MN531301 }\end{array}$ & $\begin{array}{l}\text { larva } \\
\text { ličinka }\end{array}$ & $2 / 2.500$ & Županja \\
\hline & $\begin{array}{l}\text { Parasitoid wasp } \\
\text { Parazitoidna osa }\end{array}$ & $\begin{array}{c}\text { unidentified } \\
\text { neidentificirana }\end{array}$ & $\begin{array}{c}\text { larva, adult } \\
\text { ličinka, imago }\end{array}$ & $39 / 2.500$ & $\begin{array}{l}\text { Novoselec, Vukovar, } \\
\text { Gunja, Zupanja }\end{array}$ \\
\hline & Lignyodes bischoffi & $\begin{array}{l}\text { morphological identifi- } \\
\text { cation } \\
\text { morfološka identifikacija }\end{array}$ & $\begin{array}{l}\text { larva } \\
\text { ličinka }\end{array}$ & $21 / 1.000$ & Sunja, Zagreb \\
\hline & Eupelmus urozonus & $\begin{array}{c}\text { Molecular genetic } \\
\text { method } \\
\text { molekularno genetička } \\
\text { metoda } \\
\text { MN531304 }\end{array}$ & $\begin{array}{c}\text { pupa } \\
\text { kukuljica }\end{array}$ & $4 / 1.000$ & Sunja, Zagreb \\
\hline \multirow[t]{4}{*}{ F. pennsylvanica } & Pteromalidae sp. & $\begin{array}{c}\text { Molecular genetic } \\
\text { method } \\
\text { molekularno genetička } \\
\text { metoda } \\
\text { MN531302 } \\
\text { MN531303 }\end{array}$ & $\begin{array}{l}\text { larva } \\
\text { ličinka }\end{array}$ & $68 / 1.000$ & Sunja, Zagreb \\
\hline & $\begin{array}{l}\text { Parasitoid wasp } \\
\text { Parazitoidna osa }\end{array}$ & $\begin{array}{c}\text { unidentified } \\
\text { neidentificirana }\end{array}$ & $\begin{array}{l}\text { adult } \\
\text { imago }\end{array}$ & $39 / 1.000$ & Sunja, Zagreb \\
\hline & $\begin{array}{c}\text { Pseudargyrotoza } \\
\text { conwagana }\end{array}$ & $\begin{array}{l}\text { morphological identifi- } \\
\text { cation } \\
\text { morfološka identifikacija }\end{array}$ & $\begin{array}{l}\text { larva } \\
\text { ličinka }\end{array}$ & $1 / 1.000$ & Sunja \\
\hline & Diptera sp. & $\begin{array}{c}\text { unidentified } \\
\text { neidentificirana }\end{array}$ & $\begin{array}{l}\text { larva } \\
\text { ličinka }\end{array}$ & $2 / 1.000$ & Sunja \\
\hline
\end{tabular}

ash seeds (Table 1). Weevil and moth larvae found in narrow-leaved ash seeds were identified based on the morphological and molecular genetic analysis, as L. enucleator and Pseudargyrotoza conwagana (Fabricius, 1775, Lepidoptera: Tortricidae), with $98.21 \%$ and $99.06 \%$ sequence similarity to reference sequences in NCBI GenBank, respectively. Wasp larvae and adults found in this ash species were not successfully identified (Figure 3).

Morphological and molecular genetic analysis of wasps in damaged seeds of green ash revealed that found pupae belong to species Eupelmus urozonus (Dalman, 1820, Hymenoptera: Eupelmidae), and larvae to family Pteromalidae (Hymenoptera), with $99.35 \%$ and $93.30 \%$ sequence similarity to reference sequences in NCBI GenBank, respectively. Wasp adults remained unidentified. Weevil larvae were identified as L. bischoff, combining their morphological characteristics according to Gosik et al. (2017) and molecular genetic analysis, because the obtained sequence was ambiguous and shared only $89.53 \%$ similarity with other L. bischoffi sequences deposited in NCBI GenBank. Moth larvae was identified based on its morphological characteristics as $P$. conwagana. Fly larvae were not successfully identified (Figure 3).

\section{DISCUSSION AND CONCLUSIONS RASPRAVA I ZAKLJUČCI}

Relatively small number of damaged and empty narrowleaved ash seeds was found in this research, implying their good health status regarding insect infestation. Although seeds of introduced green ash revealed higher insect occupation, especially those collected in the urban area, most of the specimens found $(81 \%)$ were parasitoids, indicating that pest populations are naturally held under control. In total, four insect taxa were identified to species level in this research, of which three can be categorised as seed pests ( $L$. 

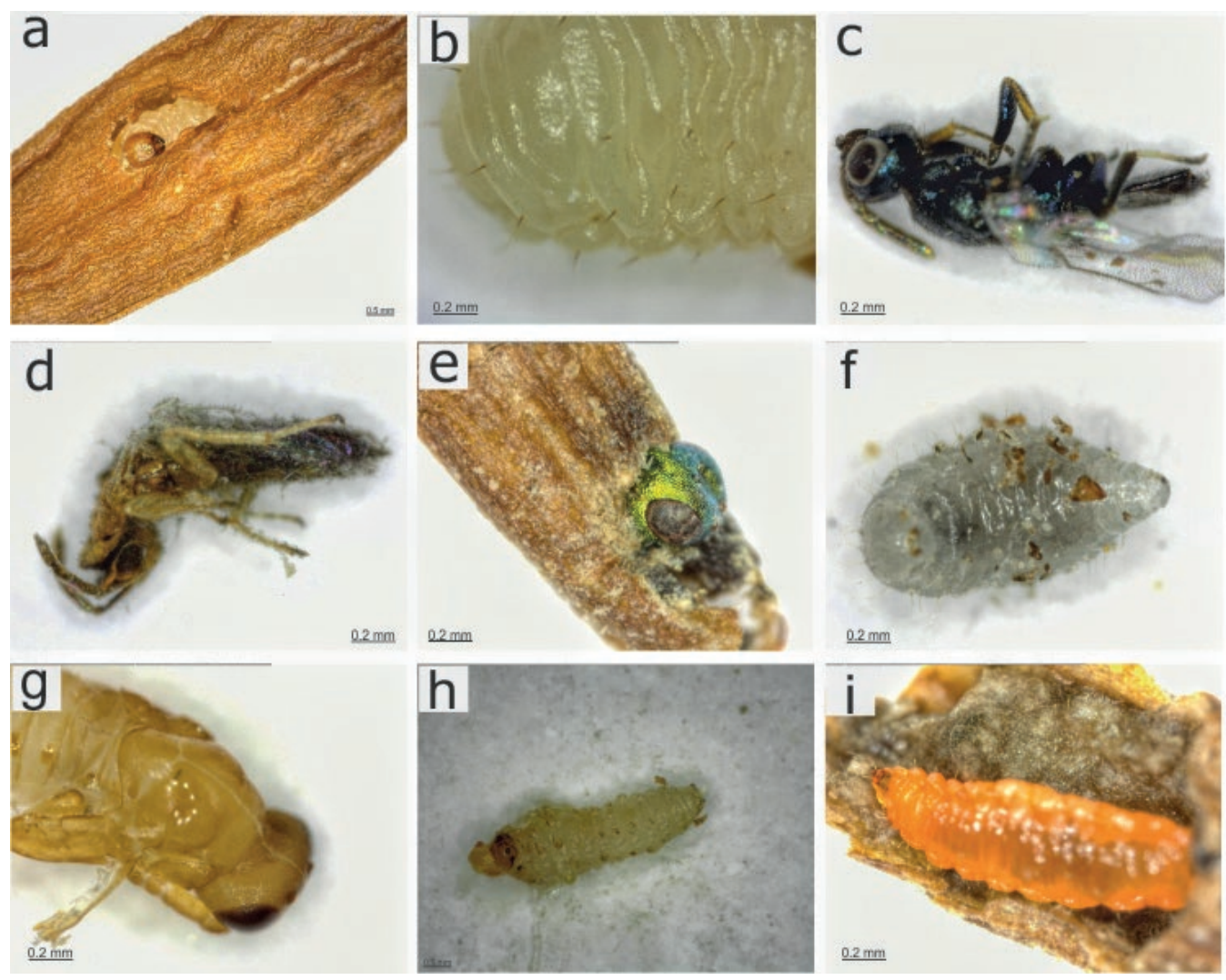

Figure 3. Some of the insect specimens found in seeds of Fraxinus angustifolia (a-c) and F. pennsylvanica (d-i): (a) Lygniodes enucleator larva; (b) Lygniodes enucletaor larva abdomen detail; (c) parasitoid wasp adult; (d) parasitoid wasp adult; (e) parasitoid wasp adult head detail; (f) parasitoid wasp larva; (g) Eupelmus urozonus pupa; (h) Pseudargyrotoza conwagana caterpillar; (i) Diptera larva

Slika 3. Neke od jedinki kukaca nađene u sjemenu poljskog jasena (a-c) i sjemenu pensilvanskog jasena (d-i): (a) ličinka Lygniodes enucleator; (b) detalj abdomena ličinke Lygniodes enucletaor; (c) imago parazitoidne ose; (d) imago parazitoidne ose; (e) detalj glave imaga parazitoidne ose; (f) ličinka parazitoidne ose; (g) kukuljica Eupelmus urozonus; (h) gusjenica Pseudargyrotoza conwagana; (i) ličinka Diptera

enucleator, L. bischoffi, P. conwagana). Other specimens were mostly parasitoid wasps in different stages, which, with the exception of E. urozonus pupae, remained unidentified.

L. enucleator, found only in native narrow-leaved ash seeds in this research, is the most common and widespread species of the Palearctic Lignyodes (Clark and Lodos 1981), present in the most part of the Europe on ash seeds and seeds of Ligustrum vulgare L. and Syringa vulgaris L. (Dieckman 1970, Mazur 2002, Arndt and Hielscher 2007, Nakladal 2011, Bacal et al. 2013, Caldara 2013, Delbol 2013). Proportion of seeds infested by L. enucleator in the present study was only $4.64 \%$ altogether, which could be a consequence of its preference towards trees that are well exposed to the sun, mostly in rural and urban biotopes (Gosik et al. 2017), and avoidance of trees growing in riparian forests, where its larvae and pupae overwintering in the soil could be inundated and killed during spring floods (Kania et al. 2001; Gosik et al. 2001). The fact that analysed seeds were collected in regularly flooded narrow-leaved ash forest stands is the most probable cause for low rate of L. enucleator presence in seeds. Therefore, it is plausible to conclude that this weevil does not represent danger to the seed health status and reproduction rate of narrow-leaved ash in its natural habitat in Croatia.

In the present study, L. bischoffi was found only in the seeds of introduced green ash. In Europe this weevil is so far confirmed in Austria, Hungary, Moldova, Poland, Russia, Slovakia, Switzerland and Ukraine, most frequently on the North American species such as F. americana L., F. nigra Marsh and F. pennsylvanica, but also on F. ornus L., F. lanceolata Borkh., F. oxyxarpa Will., and F. excelsior (Dieckmann 1974, Clark 1980, Caldara 2013, Bacal et al. 2013, Arzanov 2013, Gosik et al. 2017). This is the first official report of L. bischoffi in Croatia. Although the proportion of seeds infested by living larvae was only $2.1 \%$ in this study, in every seed where wasp larva was found there was a dead larva of the weevil as well; and since the ash seeds were collected at the beginning of November, some larvae had already left the seeds, leaving an exit hole. Combining those findings, the actual proportion of infested seeds was around $16 \%$, but was significantly decreased by the present parasitoids. The fact that L. bischoffi prefers urban areas and trees surrounded by grassy areas well exposed to the sun 
(Wanat and Gosik 2003, Gosik 2006), could also explain its absence in the part of analysed seeds, as one of two sampling locations was a floodplain forest stand (Sunja).

The other pest found on both ash species in this research was $P$. conwagana, a phytophagous moth from Lepidoptera family widespread through the Eurasia region on the plants belonging to genera Ligustrum, Fraxinus, Syringa and Berberis (Tapper 1992). In Europe large numbers of its caterpillars were reported in seeds of common ash in England, causing 15-36\% seed loss (Gardner 1977), and also in Sweden (Tapper 1992, Hayatgheibi 2013), Slovakia (Kollar 2007), Lithuania (Ostrauskas 2004) and Poland (Kubasik 2011). There are no reports of this pest in narrow-leaved ash and green ash seeds generally, nor was it found in Croatia before. Currently, P. conwagana is not a threat to the examined ash species in Croatia, since it was found in only two narrowleaved ash seeds from Županja and in one green ash seed from Sunja (both in woodland areas). Regarding narrowleaved ash, the low infestation rate could be the consequence of a decrease in seed production (Vincenc 2015, 2016, 2017, 2018, 2019), as Janzen (1971) reports that natural fluctuations of ash species in seed production lead to lower rates of moth infestation. However, this explanation is not applicable to green ash, and it might be that in Croatia ash species are not the primary source of food for this seed-feeding tortricid, but rather some other plant species.

In the seeds of both species of ash, parasitoid wasps were detected in the larval, pupal, and adult stages. The only determined species was E. urozonus collected from the green ash seeds from both sampling locations. This wasp is considered to be exceptionally polyphagous, as it occurs on hosts belonging to Lepidoptera (Gelechiidae, Oecophoridae, Tortricidae), Coleoptera (Bruchidae, Curculionidae, Scolytidae), Diptera (Agromyzidae, Cecidomyiidae, Tephritidae), Neuroptera (Chrysopidae) and Hymenoptera (Cynipidae, Braconidae, Tenthredinindae, Ichneumonidae) (Gibson and Fusu 2016). Although E. urozonus is reported to be established throughout Europe (Gibson and Fusu 2016), this is the first official report of its presence in Croatia. Comparing found specimens of adult wasps with the descriptions in the literature ( $\mathrm{Al}$ khatib et al. 2014), there is a possibility that some of the acquired adults could also be E. urozonus, but this requires further investigation. Larval stages of parasitoid wasps found in green ash where determined to belong to Pteromalidae family, which is the largest family within superfamily Chalcidoidea with over 3.500 mostly parasitic species, often difficult to determine (Burks 2009). Wasp larvae in narrow-leaved ash and adults found in both species of ash could not be identified by molecular genetic analysis due to their small numbers and size, but were identified by their morphological characteristics as parasitoid wasps. For further determination they require a more detailed examination.
Comparing the health status of the seeds of the native narrow-leaved ash and the introduced green ash, the native seeds were generally in a better state. As for green ash seeds, those collected from a forest stand (Sunja) were less damaged by insects than the ones collected from the urban park in Zagreb, which is in accordance with the claim that L. bischoffi most often occurs in the urban areas (Wanat and Gosik 2003, Gosik 2006). Considering that two most numerous pests found in this study, L. enucleator and L. bischoffi prefer urban areas, that relatively large number of parasitoids was found in the seeds and on their larvae, and that other pests were present in a very small number of seeds, it can be concluded that insects currently do not have a significant negative impact on the reproduction of narrow-leaved ash and green ash in forest stands.

\section{ACKNOWLEDGEMENT}

ZAHVALA

We thank Croatian Forests Ltd. for providing samples for this research and Mirjana Grahovac-Tremski for kindly providing all the necessary information regarding seed origin, collection and storage.

\section{REFERENCES LITERATURA}

- Al khatib, F., L. Fusu, A., Cruaud, G., Gibson, N., Borowiec, J.Y., Rasplus, N., Ris, G., Delvare, 2014: An integrative approach to species discrimination in the Eupelmus urozonus complex (Hymenoptera, Eupelmidae), with the description of 11 new species from the Western Palaearctic, Systematic Entomology, 39: 806-862.

- Arndt, E., S., Hielscher, 2007: Ground beetles (Coleoptera: Carabidae) in the forest canopy: species composition, seasonality, and year-to-year fluctuation. In: M. Unterseher, W. Morawetz, S. Klotz, E. Arndt (eds.), The canopy of a temperate floodplain forest. Results from five years of research at the Leipzig Canopy Crane, Universitätsverlag, 106-110, Leipzig.

- Arzanov, Y. G., 2013: Lignyodes bischoffi Blatchley, 1916 (Curculionidae) - A New Species of Invasive Weevils for Russia, Russian Journal of Biological Invasion, 4 (4): 209-211.

- Bacal, S., N., Munteanu, I., Toderaș, 2013: Checklist of beetles (Insecta: Coleoptera) of the Republic of Moldova, Acta Musei, 8 (3): 415-450.

- Battisti, A., A., Roques, F., Colombari, G., Frigimelica, M., Guido, 1999: Efficient transmission of an introduced pathogen via an ancient insect-fungus association, Naturwissenschaften, 86 (10): 479-483.

- Benson, D. A., M., Cavanaugh, K., Clark, I., Karsch-Mizrachi, D. J., Lipman, J., Ostell, E. W., Sayers, 2017: GenBank, Nucleic Acids Research, 45 (1): 37-42.

- Boivin, T., M.-A., Auger-Rozenberg, 2016: Native Fruit, Cone and Seed Insects in the Mediterranean Basin, In: T. Paine, F. Lieutier (eds.), Insects and Diseases of Mediterranean Forest Systems, Springer, 47-88, Cham. 
- Burks, R. A., 2009: Phylogenetics of Pteromalidae and Eulophidae (Hymenoptera: Chalcidoidea) With a Study of Cranial Bridges in Chalcidoidea, Doctoral dissertation, University of California Riverside.

- Caldara, R., 2013: Curculionidae: Curculioninae, Catalogue of Palaearctic Coleoptera, 8: 51-56.

- Caudullo, G., T. H., Durrant, 2016: Fraxinus angustifolia in Europe: distribution, habitat, usage and threats, European Atlas of Forest Tree Species, Publ. Off. EU, 97-97, Luxembourg.

- Clark, W. E., 1980: Revision of Nearctic Weevils of the Genus Lignyodes Dejean (Coleoptera: Curculionidae), Transactions of the American Entomological Society, 106 (3): 273-326.

- Clark, W. E., N., Lodos, 1981: Notes on Turkish Lignyodes Dejean (Coleoptera: Curculionidae) with description of a new species, The coleopterists bulletin, 35 (3): 311-315.

- Delbol, M., 2013: Catalogue des Curculionoidea de Belgique (Coleoptera: Polyphaga), Belgian Journal of Entomology, 13: $1-95$.

- Dieckmann, L., 1970: Die paläarktischen Lignyodes-Arten, einer schließlich einer neuen Art aus der Slowakei (Coleoptera, Curculionidae), Entomol. Nachr., 14: 97-104.

- Dieckmann, L., 1974: Beitrag über mitteleuropäische Rüsselkäfer (Coleoptera, Curculionidae), Entomol. Nachr., 18: 65-70.

- Diminić, D., 2015: Nova bolest jasena (Fraxinus spp.) u Hrvatskoj, In: S. Matić, F. Tomić, I. Anić, (eds.), Proizvodnja hrane i šumarstvo - temelj razvoja istočne Hrvatske, Hrvatska akademija znanosti i umjetnosti (HAZU), 363-373, Zagreb.

- Drescher, A., B., Prots, 2016: Fraxinus pennsylvanica-an invasive tree species in Middle Europe: case studies from the Danube basin, Contribuţii Botanice, 51: 55-69.

- Drvodelić, D., M., Oršanić, 2016: Procjena vitaliteta svježeg i preležanog sjemena poljskog jasena (Fraxinus angustifolia Vahl), Šumarski list, 140 (11-12): 539-547.

- Folmer, O., M., Black, W., Hoe, R., Lutz, R., Vrijenhoek, 1994: DNA primers for amplification of mitochondrial cytochrome $\mathrm{c}$ oxidase subunit I from diverse metazoan invertebrates, Mol. Mar. Biol. Biotechnol., 3: 294-299.

- Gardner, G., 1977: The reproductive capacity of Fraxinus excelsior on the Derbyshire limestone, Journal of Ecology, 65: 107118.

- Gibson, G. A. P., L., Fusu, 2016: Revision of the Palaearctic species of Eupelmus (Eupelmus) Dalman (Hymenoptera: Chalcidoidea: Eupelmidae), Zootaxa, 4081 (1): 1-331.

- Gosik, R., J., Łętowski, T., Mokrzycki, M., Wanat, 2001: Lignyodes bischoffi (Blatchley, 1916) (Coleoptera: Curculionidae) - gatunek nowy w faunie Polski, Wiadomości Entomologiczne, 29: 43-48.

- Gosik, R., 2006: Weevils (Curculionoidea) of the middle part of the Bug River Valley, Ann. Uni. Mariae Curie-Sklodowska Sect. C, 61: 7-69.

- Gosik, R., J., Skuhurovec, I., Toševski, R., Caldara, 2017: Morphological evidence from immature stages further suggests Lignyodina being close to Tychiina (Coleoptera, Curculionidae, Curculioninae, Tychiini), Zootaxa, 4320 (3): 426-446.

- Gross, A., T., Hosoya, V., Queloz, 2014: Population structure of the invasive forest pathogen Hymenoscyphus pseudoalbidus, Molecular Ecology, 23 (12): 2943-2960.

- Hayatgheibi, H., 2013: Studies on the microflora associated with the seeds of European ash (Fraxinus excelsior) and the infection biology of the pathogen Hymenoscyphus pseudoalbidus causing ash dieback, Master Thesis, Swedish University of Agriculture Science.

- Hulme, P. E., C. W., Benkman, 2002: Granivory, Plant-animal interactions: an evolutionary approach, Blackwell, 185-208, Oxford.

- Janzen, D. H., 1971: Seed predation by animals, Annual Review Ecology and Systematics, 2: 465-492.

- Kania, J., T., Mokrzycki, J., Szypuła, M., Wanat, 2001: Lignyodes enucleator (Panzer, 1798) (Coleoptera, Curculionidae) - gatunek w ekspansji w Polsce, Wiadomości Entomologiczne, 19: 43-48.

- Kollar, J., 2007: The harmful entomofauna of woody plants in Slovakia, Acta entomologica serbica, 12 (1): 67-79.

- Kranjec Orlović, J., I., Andrić, I., Bulovec, D., Diminić, 2019: Mycobiota in the seeds of narrow-leaved ash (Fraxinus angustifolia Vahl), Šumarski list, 143 (3-4): 103-110.

- Kremer, D., J., Čavlović, 2005: Distribution of Introduced North American Ash Species and Their Role in Lowland Forest Management in Croatia, Journal of Forestry, 103 (6): 309-313.

- Kubasik, W., 2011: Tortricidae (Lepidoptera) of Wielkopolska province with comments on rare species, Polish journal of entomology, 80: 505-516.

- Luchi, N., V., Mancini, M., Feducci, A., Santini, P., Capretti, 2011: Leptoglossus occidentalis and Diplodia pinea: a new insect-fungus association in Mediterranean forests, Forest Pathology, 42 (3): 246-251.

- Mazur, M., 2002: The distribution and ecology of weevils (Coleoptera: Nemonychidae, Attelabidae, Apionidae, Curculionidae) in western Ukraine, Acta zoologica cracoviensia, 45 (3): 213-244.

- Milotić, M., J., Kranjec, D., Diminić, 2016: Current status of ash dieback disease Hymenoscyphus fraxineus in Croatia, In: I. Radojčić Redovniković, V. Gaurina Srček, K. Radošević, T. Jakovljević, R. Stojaković, D. Erdec Hendrih (eds.), Natural resources, green technology \& sustainable development GREEN/2, University of Zagreb Faculty of Food Technology and Biotechnology, 124-124, Zagreb.

- Nakai, Z., T., Kondo, S., Akimoto, 2011: Parasitoid attack of the seed-feeding beetle Bruchus loti enhances the germination success of Lathyrus japonicus seeds, Arthropod-Plant Interactions, 5 (3): 227-234.

- Nakladal, O., 2011: Results of a faunistic survey of beetles (Coleoptera) in Hejtmanka Nature Reserve (Czech Republic, northern Moravia, Litovelské Pomoraví Protected Landscape Area) in 2009, Acta Mus. Beskid., 3: 103-129.

- Ostrauskas, H., 2004: Moths Caught in Pheromone Traps for American White Moth (Hyphantria Cunea Dr.) (Arctiidae, Lepidoptera) in Lithuania During 2001, Acta Zoologica Lituanica, 14 (1): 66-74.

- Prots, B., A., Drescher, B., Vykhor, 2011: Invasion ecology of Green Ash Fraxinus pennsylvanica Marsh. in the Transcarpathia (Ukraine). Біологічні системи, 3: 269-276.

- Ratnasingham, S., P. D., Hebert, 2007: BOLD: The Barcode of Life Data System (http://www.barcodinglife.org), Molecular ecology notes, 7 (3): 355-364.

- Sallabanks, R., S. P., Courtney, 1992: Frugivory, seed predation, and insect-vertebrate interactions, Annual Review of Entomology, 37: 377-400.

- Schmiedel, T., J., vom Brocke, J., Recker, 2013: Which cultural values matter to business process management?, Business Process Management Journal, 19 (2): 292-317. 
- Tapper, P., 1992: Irregular fruiting in Fraxinus excelsior, Journal of Vegetation Science, 3: 41-46.

- Temunović, M., J., Franjić, Z., Šatović, M., Grgurev, N., FrascariaLacoste, J. F., Fernández-Manjarrés, 2012: Environmental Heterogeneity Explains the Genetic Structure of Continental and Mediterranean Populations of Fraxinus angustifolia Vahl, PLoS ONE 7 (8): e42764.

- Turgeon, J. J., A., Roques, P., De Groot, 1994: Insect Fauna of coniferous seed cones: diversity, host plant interactions and management. Annual Review of Entomology 39: 172-212.

- Vincenc, G., 2015: Rezultati sakupljanja sjemena: Lužnjak dobro, jasen nikako, Hrvatske šume, 217/218: 17.
- Vincenc, G., 2016: Proizvodnja šumsko-rasadničkog materijala: Pojavljuju se znakovi oporavka jasena, Hrvatske šume, 231: 20 21.

- Vincenc, G., 2017: Proizvodnja 2016.: Bukva na kontinentu odlična, u gorskoj Hrvatskoj slaba, Hrvatske šume, 244: 32-33.

- Vincenc, G., 2018: Rezultati proizvodnje 2017.: Unatoč lošim predviđanjima, godina u rangu prethodnih, Hrvatske šume, 256: $28-29$.

- Vincenc, G., 2019: Rezultati proizvodnje 2018.: Jasen i četinjače i dalje loše, sveukupno dobro, Hrvatske šume, 268: 26-27.

- Wanat, M., R., Gosik, 2003: Materialy do znajomo ci ryjkowców (Insecta: Coleoptera: Curculionoidea) doliny Bugu, Nowy Pam. Fizjogr. (Warszawa), 2 (1-2): 31-52.

\section{SAŽETAK}

Autohtoni poljski jasen (Fraxinus angustifolia Vahl) i alohtoni pensilvanski jasen (F. pennsylvanica Marshall) su dvije najčešće vrste roda Fraxinus prisutne u nizinskim šumama Hrvatske, zbog čega zauzimaju važno mjesto u ovim šumskim ekosustavima. Posljednjih godina je zapaženo smanjenje uroda sjemena poljskog jasena, naglašavajući važnost dobrog zdravstvenog stanja sakupljenih količina, jer se sjeme koristi za proizvodnju sadnica koje se dalje upotrebljavaju za pomlađivanje šumskih sastojina ili pošumljavanje. Kako kukci mogu imati velik utjecaj na zdravstveno stanje sjemena, cilj ovog istraživanja je bio dobiti uvid u prisutne vrste i njihovu učestalost u sjemenu jasena. Prisutnost kukaca je analizirana u ukupno 2.500 sjemenki poljskoga i 1.000 sjemenki pensilvanskog jasena. Promatrano sjeme je kategorizirano kao neoštećeno, oštećeno i prazno (šturo), a nađene jedinke kukaca su identificirane na temelju morfoloških karakteristika i korištenjem molekularno genetičke analize. Sjeme pensilvanskog jasena pokazalo je veću oštećenost kukcima u usporedbi sa sjemenom poljskoga jasena, pri čemu je pipa Lygniodes bischoffii bila najčešći utvrđeni štetnik. Oštećeno sjeme poljskog jasena je najčešće bilo nastanjeno autohtonom vrstom pipe, L. enucleator. Osim navedenih štetnika, u sjemenu obje vrste jasena su nađene ličinke, kukuljice i imaga parazitoidnih osa (Hymenoptera) te ličinke štetnika Pseudargyrotoza conwagana (Lepidoptera). S obzirom da štetnici utvrđeni u istraživanju preferiraju urbana područja ili su nađeni na vrlo malom broju sjemena, često zajedno sa parazitoidima, može se zaključiti kako kukci trenutno nemaju značajan negativan utjecaj na zdravstveno stanje sjemena poljskog i pensilvanskog jasena u šumskim sastojinama.

KLJUČNE RIJEČI: jasen, oštećenost sjemena, pipe, Lygniodes, parazitoidne ose, Pseudargyrotoza conwagana 